\title{
In vitro cytotoxic study of Croton caudatus Geiseler - a tradi- tionally known anticancerous plant in North-east India
}

\author{
Biplab De ${ }^{1}$, Indrani Mitra ${ }^{1}$, Manabendra Dutta Choudhury², Satya Bhusan Paul, \\ Lokesh Deb ${ }^{4}$, Amitabha De $^{5}$ and Rumki Nath ${ }^{2,6}$ \\ ${ }^{1}$ Regional Institute of Pharmaceutical Science and Technology, Abhoynagar, Agartala, Tripura 799005, India \\ ${ }^{2}$ Department of Life Science \& Bioinformatics, Assam University, Silchar 788011, India \\ ${ }^{3}$ Department of Chemistry, Assam University, Silchar 788011, India \\ ${ }^{4}$ Institute of Bioresources and Sustainable Development, Gangtok, Sikkim 737102, India \\ ${ }^{5}$ Institute of Bioresources and Sustainable Development, Imphal, Manipur 795004, India \\ ${ }^{6}$ Corresponding author, e-mail: rumki_nath2000@yahoo.com
}

[Received 28.06.2018; Revised 06.12.2018; 12.12.2018; Published 31.12.2018]

\begin{abstract}
Plants and plant products both as extract and derived compounds are known to be used as chemopreventive agents against various types of cancer. Identification of phytochemicals is found to be an effective chemopreventive agent in the field of chemoprevention research. Pharmacological and clinical investigations of medicinal plants have provided a wide variety of natural compounds possessing significant cytotoxic as well as chemopreventive activity. Cytotoxicity testing is based on one or more mammalian cell lines being grown under conditions where they are actively growing and undergoing mitotic division. Cells are cultured in a microtitre well plate and the rate of multiplication and growth is measured indirectly by the formation of a colour, the intensity of which is directly proportional to the number of cells present. The present study shows the in vitro cytotoxic activity of the methanol extract of the leaves of Croton caudatus Geiseler on HeLa cells ( human cervical cancer cell lines) and suggests further screening and isolation of natural active cytotoxic components.
\end{abstract}

Key words: Croton caudatus, Cytotoxic activity, SRB Assay, MTT Assay

\section{INTRODUCTION}

Traditionally used medicinal plants are supposed to be the richest sources of bioactive chemicals those act through a large variety of mechanisms to combat different types of diseases (Nath et al. 2014). Herbal medicines have been used for various treatments from the days of the caveman. Traditional medicines has been widely used to heal cancer in about $75-80 \%$ of world population (Cha 1977; Gupta 1979; Hussain et al. 1993; Rabi \& Gupta 1995). Fortyseven percent of the anticancer drugs in the market come from natural products or are natural product mimics. As natural products or secondary metabolites are being elaborated within living systems, these are often perceived of showing more biological friendliness and drug likeliness than totally synthetic compounds (Koehn \& Carter 2005) thus making such metabolites good candidates for drug development.

Cancer is an abnormal type of tissue growth in which the cells exhibit an uncontrolled division, relatively in an autonomous fashion, leading to a progressive increase in the number of dividing cells (Wayne et al. 2006). An extremely promising strategy for cancer prevention today is chemoprevention, which is defined as the use of synthetic or natural agents to block the development of cancer in humans. A variety of bioactive compounds and their derivatives 
have been shown to inhibit carcinogenesis in a number of experimental systems involving initiation, promotion, and progression (Ho et al. 1994; Huang et al. 1994). By introducing a successful bioactive component of an anticancer drug with minor side effects on normal cells and high tumor selectivity, natural products could serve as a chemopreventive and chemotherapeutic agent (Mehta et al. 2010). Many traditional medicines have remarkable biological activities with potential therapeutic drugs such as taxol from Taxus brevifolia Nutt., camptothecin from Camptotheca acuminata Decne, vinca alkaloids from Catharanthus roseus (L.) G.Don and podophyllotoxin from Podophyllum peltatum L. are extensively used in clinical trials (Taran et al. 2010).

Croton is an extensive plant genus of Euphorbiaceae established in 1753 by Carolus Linnaeus in his Species Plantarum (page no. 1004). The genus Croton comprises of around 1,300 species of trees, shrubs, and herbs distributed in tropical and subtropical regions of both the hemispheres (Block et al. 2004). Several species of Croton have long role in the traditional use as medicinal plants in Africa, Asia and South America. Popular uses include treatment of cancer, constipation, diabetes, digestive problems, dysentery, external wounds, fever, hypercholesterolemia, hypertension, inflammation, intestinal worms, malaria, pain, ulcers and weight-loss (Salatino et al. 2007). Croton caudatus Geiseler has curative medicinal properties for cancer, diabetes, malaria, and indigestion. Leaves are claimed to have anticancer property and are a potential source of natural antioxidants (Deore et al. 2009). Presence of dotriacontamol, bomyrin and b-sitosterol in the roots and barks of the plant have been detected which are used in the treatment of ailments related to calcarious (cancer), as per the reports from the Central Drug Research Institute, Lucknow (http://www.miusal.com/,Scientific name of probable anticancer plant identified, June $\left.11^{\text {th }}, 2008\right)$. Methanol and aqueous extracts of Croton caudatus leaves have been reported to show potent in vivo anticancer activity against Dalton's Lmphoma while in vitro cytotoxic activity was reported only with the aqueous extract (Rosangkima \& Jagetia 2015).

Cervical cancer is the second malignant tumor morbidity of women worldwide which ranks just behind breast cancer. It takes away nearly 27 million women's lives every year and has been severely threatening the health and life of women (Yang et al. 2004; Ferlay et al. 2007; Cohen 2005). The aim of this study was to examine the in vitro cytotoxic activity of crude methanol extract of leaves of Croton caudatus on HeLa cells (human cervical cancer cell line) using MTT assay and SRB Assay.

\section{MATERIALS AND METHODS}

Preparation of plant extract: Croton caudatus Geiseler plant was collected from Assam University campus and authenticated by curator of Assam University Herbarium, (AUS/ 1903). The collected leaves were shade dried and ground into powder in a grinder machine. The prepared powder was kept in air tight containers protected completely from light. The powdered plant material was extracted with methanol in a Soxhlet Apparatus for 48 hours. The methanol extract was filtered and then evaporated to dryness. The concentrated extract was used for determining the cytotoxic activity.

Cell cultures: The human cervical adenocarcinoma cell line (HeLa) was obtained from the National Centre for Cell Science (Pune, India). These were grown as monolayer cultures in DMEM ( Dulbecco's modified Eagle's medium ) supplemented with $10 \%$ (v/ v) heat-inactivated fetal bovine serum (FBS) and $1 \%$ antibiotic-antimycotic solution (1000 $\mathrm{U} / \mathrm{ml}$ penicillin, $10 \mathrm{mg} / \mathrm{ml}$ streptomycin sulfate, $5 \mathrm{mg} / \mathrm{ml}$ gentamycin and $25 \mu \mathrm{g} / \mathrm{ml}$ amphotericin-B), and maintained at $37^{\circ} \mathrm{C}$ in $5 \% \mathrm{CO}_{2} / 95 \%$ air with $90 \%$ relative humidity. 
SRB (Sulphorhodamine) exposure assay: Sulphorhodamine B (SRB) assay relies on the uptake of the negatively charged pink aminoxanthine dye, sulphorhodamine B (SRB) by basic amino acids in the cells. The greater the number of cells the greater amount of dye is taken up and, after fixing when the cells are lysed, the released dye will give up a more intense colour and greater absorbance (Skehan et al. 1990).

\section{Procedure for SRB exposure assay:}

1. $100 \mu \mathrm{l}$ of HeLa cell suspension of optimum density was introduced into each well of 96 well plates.

2. A range of concentration of the substance (leaf extract) was made in the culture medium so that, when diluted $2 \mathrm{x}$, the range of final concentration in the well is 100 to $0.2 \mu \mathrm{g} / \mathrm{ml}$ for extracts. A range of concentrations for a known cytotoxic agent e.g. vincristine sulfate (Sigma-Aldrich, UK) was used as a positive control.

3. $100 \mu 1$ of each concentration of test sample in culture medium was added to the wells containing the cells. $100 \mu 1$ of the medium only was added to the control wells.

4. The cells were incubated with the samples for $48 \mathrm{hrs}$.

5. The cells were then fixed with ice-cold TCA for $1 \mathrm{hr}$ at $4^{\circ} \mathrm{C}$.

6. The plates were washed five times in distilled water and allowed to dry in the air.

7. $50 \mu \mathrm{l}$ (SRB) sulphorhodamine solution was added to each well of the dried 96-well plates and allowed staining at room temperature for $30 \mathrm{~min}$.

8. SRB solution removed and the plates were washed with $1 \% \mathrm{v} / \mathrm{v}$ acetic acid five times to remove unbound dye.

9. The washed plates were dried in air. The bound SRB was solubilised by adding 100 $\mu 1$ of $10 \mathrm{mM}$ unbuffered Tris Base $(\mathrm{pH} 10.5)$ to each well and shaken for five minutes on a shaker platform.

10. The plates were read in a 96-well plate reader e.g. Spectra-Max-190 (Molecular Devices, Sunnydale, USA) with the working wavelength of $492 \mathrm{~nm}$ (Giuseppe et al. 2006; Houghton et al. 2007).

Procedure for MTT assay: The assay detects the reduction of MTT ( SIGMA, USA) by mitochondrial dehydrogenase to blue formazan product, which reflects the normal function of mitochondria and hence for measuring the cytotoxicity, and cell viability (Shahneh et al. 2013). The cytotoxicity analysis was determined using the MTT assay as reported by Mosmann (Mossmann 1983). HeLa cells grown in T-25 culture flasks were harvested by trypsinization, plated at an approximate density of $1 \times 10^{5}$ cells/well in 96 well culture plates (Corning, Sigma) and incubated for $24 \mathrm{hrs}$ to achieve confluence. Next, the medium from each well was removed and the cells washed twice with Dulbecco's phosphate buffered saline (PBS). The cells were then exposed to increasing concentration of the extract. Each well contained $100 \mu 1$ of serumfree DMEM containing the different concentration of extract. The cells were then incubated at $37^{\circ} \mathrm{C}$ in $5 \% \mathrm{CO}_{2} / 95 \%$ air with $90 \%$ relative humidity for $24 \mathrm{hrs}$. After incubation, the contents were replaced with equal amounts of MTT dissolved in serum-free DMEM (1.2 $\mathrm{mM}$ ) after which the equal amount of DMSO to solubilise the formazan grains formed by viable cells. Finally, the absorbance was read at $570 \mathrm{~nm}$ using a multi-well plate reader (Spectra -Max-190). The viability $\%$ was determined by using the formula as suggested by Moriangthem et al. (2012).

Viability \% = Absorbance of the test sample/Absorbance of the control x 100 The concentration of the cells that killed $50 \%$ of the cells $\left(\mathrm{IC}_{50}\right)$ was calculated by MSEXCEL software. 
Statistical analysis: All the values were expressed as the mean of three replicates \pm SEM (standard error of the mean).

\section{RESULT}

Table 1. \% Cytotoxicity of methanol extract of Croton caudatus Geiseler leaves and the standard drug vincristine against HeLa cells as observed by SRB Assay.

\begin{tabular}{|c|c|c|}
\hline \multirow{2}{*}{$\begin{array}{c}\text { Concentration } \\
(\boldsymbol{\mu g} / \mathbf{m} \mathbf{L})\end{array}$} & \% Cytotoxicity \pm SEM \\
\cline { 2 - 3 } & Extract & Standard drug (Vincristine) \\
\hline 10 & $10.71 \pm 0.031$ & $24.60 \pm 0.032$ \\
\hline 20 & $11.87 \pm 0.039$ & $40.02 \pm 0.035$ \\
\hline 40 & $22.45 \pm 0.022$ & $55.36 \pm 0.023$ \\
\hline 80 & $32.99 \pm 0.041$ & $83.89 \pm 0.041$ \\
\hline 100 & $44.35 \pm 0.016$ & $92.67 \pm 0.022$ \\
\hline
\end{tabular}

Table 2. In vitro cytotoxic activity of methanol extract of Croton caudatus Geiseler leaves and vincristine against HeLa cell culture by MTT Assay.

\begin{tabular}{|c|c|c|}
\hline \multirow{2}{*}{$\begin{array}{c}\text { Concentration } \\
(\boldsymbol{\mu g} / \mathbf{m L})\end{array}$} & Extract & $\begin{array}{c}\text { \% Cell viability } \pm \text { SEM } \\
\text { Standard drug } \\
\text { (Vincristine) }\end{array}$ \\
\cline { 2 - 3 } & $93.32 \pm 0.033$ & $76.40 \pm 0.023$ \\
\hline 10 & $82.31 \pm 0.042$ & $61.31 \pm 0.031$ \\
\hline 20 & $56.36 \pm 0.022$ & $46.42 \pm 0.039$ \\
\hline 40 & $36.21 \pm 0.041$ & $18.24 \pm 0.042$ \\
\hline 80 & $19.74 \pm 0.036$ & $9.41 \pm 0.022$ \\
\hline 100 & 59.70 & 39.46 \\
\hline $\mathrm{IC}_{50}$ value & & \\
\hline
\end{tabular}

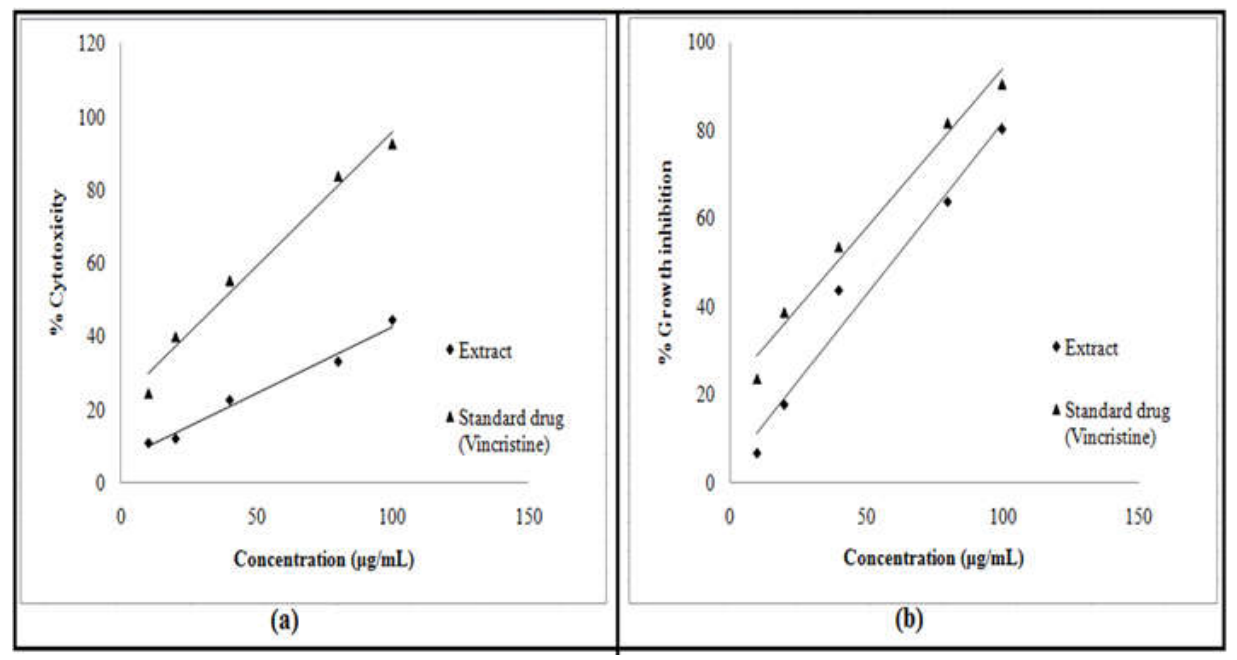

Figure 1. Graphical representation of $\mathrm{MeOH}$ extract of Croton caudatus Geiseler leaves and the standard drug vincristine against HeLa cells showing: (a) \% cytotoxicity based on SRB Assay and (b) \% growth inhibition (100 - \% viability) based on MTT assay. 


\section{DISCUSSION}

Historically ethnomedicine has been used for maintaining health, boosting immune system function, moreover prevention, therapy, and remission of cancer. A natural product can serve as a chemopreventive and chemotherapeutic agent, because of minor side effects on normal cells as seen in a clinical trial (Mehta 2010). Researches on the anticancer activity of plant constituents from both domestic and foreign sources has been in existence for decades. The possible mechanism of antitumor activity in some plant drugs has also been successfully explained to some extent (Xia et al. 2013). A successful anticancer compound should kill or incapacitate cancer cells without causing excessive damage to normal cells. Certain products from plants are known to induce apoptosis in cancer cells but not in normal cells. Thus it is important to screen apoptotic inducers from plants either in the form of crude extracts or as active isolated components (Babior et al. 1973). Phytochemicals are extensively used as chemopreventive agents capable of inhibiting cell proliferation, inducing apoptosis or signal transduction in in vitro and in animal models (Tuyns et al. 2001; Mullayer et al. 2001). Hence, this scenario is undertaken to cram the Croton caudatus crude methanol extract as a chemopreventive or chemotherapeutic drug.

The MTT assay is based on the capacity of the mitochondrial succinate dehydrogenase enzymes in living cells to reduce the yellow water-soluble substrate 3-(4,5-dimethyl thiazol 2-yl) -2,5-diphenyl tetrazolium bromide into an insoluble, coloured formazon product which is measured spectrophotometrically. Since the reduction of MTT can occur in metabolically active cells, the level of activity is a measure of the viability of the cells (Kanchana \& Balakrishnan 2011). The results of the MTT assay (Table 2) showed that with an increase in the concentration of the test sample the \% cell viability of HeLa cells decreased, thus showing an increasing activity of the crude extract against the increase in its concentration. As seen in case of the standard drug vincristine the \% cell viability for $100 \mu \mathrm{g} / \mathrm{ml}$ was $9.41 \pm 0.022$ and the same for the crude extract was $19.74 \pm 0.036$. The highest concentration displayed the lowest cell viability thus showing a concentration-dependent activity of the compound. The result revealed a promising cytotoxicity of the methanol extract and the $\mathrm{IC}_{50}$ for vincristine and the crude extract was found to be 39.46 and 59.70 respectively. As per the SRB assay result (Table 1) the plant extract showed considerable activity on HeLa cells. It was seen that the $\%$ cytotoxicity increased with an increase in the concentration of the crude extract. The highest concentration $(100 \mu \mathrm{gm} / \mathrm{ml})$ displayed the highest $\%$ cytotoxicity $(44.35 \pm 0.016)$. The graphical representation of the $\%$ cytotoxicity and $\%$ growth inhibition (100 - $\%$ viability) is shown in Figure 1. To our knowledge, there was no previous study on the in vitro cytotoxic activity of crude methanol extract of the leaves of Croton caudatus on HeLa cells.

\section{CONCLUSION}

In this study, the methanol extract of the leaves of Croton caudatus Geiseler (Euphorbiaceae) has been found to exert promising in vitro cytotoxic activity. Results of the MTT assay and SRB assay with the extract indicated that the extract was most effective in inducing cytotoxicity of HeLa cells and justifies the ethnomedicinal use of this plant to treat cancer patients. Also, further work may be carried out on this plant part to establish different bioactivity and for the isolation of natural active cytotoxic components.

\section{LITERATURE CITED}

Babior, B.M.; Kipnes, R.S. \& Curnutte, J.T. 1973. Biological defence mechanism: the production of superoxide by leukocytes a potential bacteriocidal agent. J. Clin. Invest. 52(3): $741-744$. 
Block, S.; Baccelli, C.; Tinant, B.; Meervelt, L.C.; Rozenberg, R.; Jiwan, J.L.H.; Labres, C.; Pauw-Gillet, M.C. \& Quetin-LecLercq. 2004. Diterpenes from the leaves of Croton zambesicus. Phytochemistry 65(8): 1165 - 1171.

Cha, S. 1977. Potential anticancer medicinal plants: A statistical evaluation of their frequencies of appearance in oriental medicine formularies. Korean J. Pharmacog. 8: 1 - 14.

Cohen, J. 2005. Public health high hopes and dilemmas for a cervical cancer vaccine. Science 308(5722): $618-621$.

Deore, S.L.; Khadabadi, S.S.; Baviskar, B.A; Khadabadi, S.S; Khangenbam, R.A.; Koli, U.S.; Daga, N.P.; Gadbail, P.A. \& Jain, P.A. 2009. In vitro Antioxidant activity and Phenolic Content of Croton caudatum. Intn. J. Chem. Tech. Res. 1(2): $174-176$.

Ferlay, J.; Autier, P.; Boniol, M.; Heanue, M. \& Colombet, M. 2007. Estimates of the cancer incidence and mortality in Europe in 2006. Ann. Oncol. 18(3): 581 - 592.

Gupta, S.K. 1979. Apocynaceous plants of Varanasi with notes on their medicinal importance. J. Res. Indian Med. Yoga Homeop. 14: 140 - 142.

Ho, C.T.; Ferraro, T.; Chen, Q. \& Rosen, R.T. 1994. Phytochemicals in teas and rosemary and their cancer preventing properties. In: C.T. Ho; T. Osawa; M. T. Huang \& R.T. Rosen (eds.), Foods Phytochemicals for Cancer Prevention. II. Tea, Spices, and Herbs. ACS Symposium Series 547, American Chemical Society, Washington, DC. Pp. $7-16$.

Houghton, P.; Fang, R.; Techatanawat, I.; Steventon, G.; Hylands, P.J. \& Lee, C.C. 2007. The sulphorhodamine (SRB) assay and other approaches to testing plant extracts and derived compounds for activities related to reputed anticancer activity. Methods. 42(4): $377-387$.

http://www.miusal.com/,Scientific name of probable anticancer plant identified, June $11^{\text {th }}, 2008$.

Huang, M. T.; Ferraro, T. \& Ho, C.T. 1994. Cancer chemoprevention by phytochemicals in fruits and vegetables: An overview. In: C.T. Ho; T. Osawa; M.T. Huang \& R.T. Rosen (eds.), Food Phytochemicals for Cancer Prevention I: Fruits and Vegetables. ACS Symposium, Series 547, American Chemical Society, Washington, DC.

Hussain, S.J.; Alvi, A.B. \& Johan, M.A. 1993. Study on Unani medicinal plants, Asteratiqus. J. Res. Edn. Indian Med. 2: 35.

Kanchana, A. \& Balakrishnan, M. 2011. Anticancer effect of saponins isolated from Solanum trilobatum leaf extract and induction of apoptosis in human larynx cancer cell lines. Intn. J. Pharm. Pharm. Sci. 3(4): $356-364$.

Koehn, F.E. \& Carter, G.T. 2005. The evolving role of natural products in drug discovery. Nat. Rev. Drug Discov. 4: 206 - 220.

Mehta, R.; Murillo, G.; Naithane, R. \& Peng, X. 2010. Cancer chemoprevention by natural products : How far have we come ? Pharm.Res. 27(6): 950 - 961.

Moriangthem, D.S.; Talukdar, N.C.; Kasoju, N. \& Bora, U. 2012. Antioxidant, antibacterial, cytotoxic and apoptotic activity of stem bark extracts of Cephalotaxus griffithii Hook.f. BMC Complement. Altn. Med. 12(1): 30

Mossmann, T. 1983. Rapid calorimetric assay for cellular growth and survival: application to proliferation and cytotoxicity assays. J. Immunol. Methods. 65(1-2): 55 - 63 . 
Nath, D.; Choudhury, M.D.; Mazumdar, P.B. \& Mitra, A. 2014. Phytochemical profiling of Melastoma malabathricum Linnaeus (Melastomataceae): an ethnomedicinally important plant of Eastern Himalaya. Pleione. 8(2): 478 - 485.

Rabi, T. \& Gupta, R.C. 1995. Antitumor and cytotoxic investigation of Amoora rohituka. Intn. J. Pharma. 33(4): 359 - 331.

Rosangkima, G. \& Jagetia, G.C. 2015. Anticancer, antioxidant and analgesic properties of Croton caudatus Geisel leaf extracts. Intn. J. Curr. Res. 7(9): 20640 - 20646.

Salatino, A.; Salatino, M.L.F. \& Negri, G. 2007. Traditional uses, chemistry and pharmacology of Croton species (Euphorbiaceae). J. Braz. Chem. Soc. 18(1): 11.

Shahneh, F.Z.; Valiyari, S.; Azadmehr, A.; Hajiaghaee, R., Bandehagh, A. \& Baradaran, B. 2013. Cytotoxic activities of Ferulago angulata extract on human leukemia and lymphoma cells by induction of apoptosis. J. Med. Pl. Res. 7(11): 677 - 682.

Skehan, P.; Storeng, R.; Scudiero, D.; Monks, A.; McMahon, J.; Vistica, D.; Warren, J.T. ; Bokesch, H.; Kenney, S. \& Boyd, M.R. 1990. New calorimetric cytotoxic assay for anticancer drug screening. J. Natl. Cancer Inst. 82(13): 1107 - 1112.

Taran, M.; Ghasempour, A. \& Shirinpour, E. 2010. Antimicrobial activity of essential oils of Ferulago angulata subsp. carduchorum. Jundishapur. J. Microbiol. 3(1): $10-14$.

Tuyns, A.J.; Estene, J.; Raymond, L.; Berrino, F.; Benhamon, E.; Blanchet, F.; Boffetta, P.; Crosignani, P.; del Moral, A. \& Lehmann, W. 2001. Cancer of the larynx/hypopharynx, tobacoo and alcohol: IARC international case -control study in Turin and Varage (Haly), Zaragoza and Navarra (Spain), Geneva (Switzerland), Calvador (France). Intn. J. Cancer. 41(4): $483-491$.

Wayne, M.B.; Lewis, J.K. \& Teff, H. 2006. The world of the cell. Benjamin Camming, New York. Xia, G.; Matsidik, R.; Ablise, M.; Lei, S. \& Abudula, A. 2013. Anticancer activity of flavonoids from Xinjiang Glycyrrhiza inflata Licorice on proliferation, cytotoxicity and apoptosis in cervical carcinoma cells. J. Med. Pl. Res. 7(5): 173.

Yang, B.H.; Bray, F.I. \& Parkin, D.M. 2004. Cervical cancer as a priority for prevention in different world regions: An evaluation using years of life lost. Intn. J. Cancer. 109(3): $418-424$. 